10 (2017) 3: 307-322

ISSN (print) 1689-5150

ISSN (online) 2450-7059

\title{
Who depends on whom? \\ On the relation between Peter Lombard's commentary on Romans and the one of Herveus of Bourg-Dieu
}

\section{Kto zależy od kogo? \\ O relacji między Komentarzami do Rzymian autorstwa Piotra Lombarda i Herweusza z Bourg-Dieu}

\begin{abstract}
In this article, Peter Lombard's commentary on Romans is compared with the one of Herveus of Bourg-Dieu by questioning, if there is a dependency between both. The comparison shows, that either there was an unknown common source which was used by both of them, or Peter Lombard used the Enarrationes of Herveus of BourgDieu; the second hypothesis is more probable and argues for dating the Lombard's Collectanea on 1148 or later.
\end{abstract}

Streszczenie. W tym artykule Komentarz do Rzymian Piotra Lombarda jest porównywany z dziełem Herveus z Bourg-Dieu. Porównanie pokazuje, że obydwaj używali wspólnego nieznanego źródła, albo Piotr Lombard posługiwał się Enarrationes Herveusa. Ta druga hipoteza jest bardzo prawdopodobna i jest argumentem za datowaniem Collectanea Piotra Lombarda na 1148 r. albo okres późniejszy.

Keywords: Peter Lombard; Herveus of Bourg-Dieu; Letter on Romans; Medieval commentaries, scriptural exegesis.

Słowa kluczowe: Piotr Lombard; Herveus z Bourg-Dieu; List do Rzymian, komentarze średnowieczne; egzegeza scrypturystyczna.

Though Peter Lombard's commentary on Paul ${ }^{1}$ is in comparison to his Four 1 Books of Sentences less popular, it was very inflentual for the whole Middle Age because of its inclusion as magna glosatura in the official' commentary of

1 On his biography and his works see: Marcia L. Colish: Peter Lombard, Leiden/New York/Cologne 1994; Philipp W. Rosemann: Peter Lombard, Oxford/New York 2004. 
the Bible, the Glossa ordinaria. ${ }^{2}$ Regarding its formation are certainly still many dubieties; one of these shall be considered in this analysis.

Ignatius Brady has proved ${ }^{3}$ the existence of two versions of Peter Lombard's commentary on the Pauline Epistles: In the second, revised edition the Lombard cites amongst others De fide orthodoxa of John Damascene; as he could have gotten to known this scripture first on a journey to Rome, this revised edition of the commentary can be dated relatively certain around the end of $1154 .{ }^{4}$ In contrast, dating the first version, on which the second edition depends, is more difficult: The primary dating on $1140^{5}$ is following a reference in the Libellus de ordine donorum Sancti Spiritus of Gerhoch of Reichersberg, which was written in 1141/1142 and in which the Lombard's commentary is referred to alongside those of Peter Abelard and Gilbert Porreta. ${ }^{6}$ However, this reference of the Lombard is obviously a later apposition of the 1160 ies. $^{7}$ Therefore the completion is today mostly assumed to have happened in the period after the Council of Reims 1148, because this theory could explain the references of the Lombard to ideas of Gilbert. $^{8}$

This article will analyse this consensus more precisely, relying on an argumentation of Marcia Colish, who pointed out that by reason of Gilbert Porreta's teaching in Paris, the Lombard could have encountered the ideas of Gilbert quite earlier; in this case the first version of the Collectanea may have been written around $1140 .{ }^{9}$ This, of course, is not a necessary consequence of the possibility of an origin before 1148. A promising starting point to substantiate this theory though is the relation of the Lombard's commentary on Paul

2 An actual research on the origin of the Glossa ordinaria is: Alexander Andrée: Anselm of Laon unveiled: The Glosae svper Iohannem and the origins of the Glossa ordinaria on the Bible, in: Mediaeval Studies 73 (2011), 217-240.

3 Cf. Ignatius Brady: Prolegomena, in: Magistri Petri Lombardi Sententiae in IV libris distinctae, ed. Ignatius Brady (Spicilegium Bonaventurianum 4), Grottaferrata 1971, $8^{\star}-129^{\star}$; in this connection the pages $62^{\star}-65^{\star}$.

4 Cf. Brady, $63^{*}$.

5 This dating is also used on the prints of the second edition, why also Migne his reproduction of the Collectanea in Epistolas S. Pauli on this year dates, cf. PL 191, $1297 \mathrm{f}$.

6 Cf. Peter Classen: Gerhoch von Reichersberg. Eine Biographie, Wiesbaden 1960, 412.

7 Cf. Classen, 412 ; Brady, $82^{\star}-84^{*}$.

8 Cf. Brady, $88^{\star}$; he is followed by: Rosemann, $44 \mathrm{f}$.

9 Cf. Colish, 23f., especially note 23. A longer teaching of Gilbert Porreta than often supposed is proved by Theresa Gross-Diaz, cf. Theresa Gross-Diaz: The Psalms Commentary of Gilbert of Poitiers. From Lectio Divina to the lecture room, Leiden/New York/Cologne 1996, 15-23. 
and another commentator: Hervaeus of Bourg-Dieu (Hervaeus Burgidolensis, Hervé of Déols) ${ }^{10}$, a monastic theologian, who wrote with his Enarrationes in Epistolas Pauli ${ }^{11}$ also a commentary on Paul, which is in several points similar or even equal to the Lombard's commentary; this was already recognized by earlier researchers, though most varyingly interpreted, for which reason it is worthy to outline the previous research on this. Then, the parallels between the Lombard and Hervaeus will be compared, aiming to find out in what way there are dependencies. Finally, two theories should explain the relation between both commentaries.

The first one who expatiated on the connection between the Lombard and Hervaeus was Hans Hermann Glunz, who outlined in 1933 in his ,History of the Vulgate in England' the genesis of the gloss as well; but he believed the Enarrationes to be wrongly attributed to Hervaeus, while actually coming from Anselm of Laon. ${ }^{12}$ According to this, Glunz made his case, that the Enarrationes were the source of Anselm's interlinear gloss on Paul. ${ }^{13}$ His argumentation, „that nearly all the glosses of the Interlinearis on Paul are almost literally anticipated, though together with other expository material, in the Ennarationes " ${ }^{14}$ is leading to the conclusion, that the Enarrationes were first written by Anselm of Laon, who adopted parts of it in his interlinear gloss, which was again adopted by Peter Lombard as - in Glunz's opinion - the real composer of the Glossa ordinaria.

Glunz was contradicted in several points comparatively quick by two notable researchers: First of all, Beryl Smalley wrote an elaborated article ${ }^{15}$ in 1936, in which she is arguing against Glunz's thesis to attribute the authorship of the

10 On his so far less probed person see basically the article of Guy Oury: Art. Hervé de Bourg-Dieu, in: DSP 7, 373-377.

11 Printed in: PL 181, 591-1692; for long time, this commentary was published under the name of Anselm of Canterbury, cf. Oury, 374.

12 Cf. Hans Hermann Glunz: History of the Vulgate in England from Alcuin to Roger Bacon. Being an Inquiry into the Text of some English Manuscripts of the Vulgate Gospels, Cambridge 1933, 204.

13 Cf. Glunz, 205.

14 Glunz, 205.

15 Beryl Smalley: Gilbertus Universalis, Bishop of London (1128-34), and the Problem of the ,Glossa Ordinaria', in: RThAM 8 (1936), 24-60. 
Glossa ordinaria to the Lombard. ${ }^{16}$ In doing so she is also referring to Hervaeus of Bourg-Dieu: By reason of its richness of detail, the Enarrationes cannot be a former version of the interlinear gloss, „on some texts they are even fuller than the Lombard's Great Gloss!" 17 Equally, Smalley is doubting the attribution of the Enarrationes to Anselm of Laon, ${ }^{18}$ which was supported somewhat later by Artur Michael Landgraf, who proved in an article the authorship of Hervaeus of Bourg-Dieu for the Enarrationes. ${ }^{19}$ Landgraf also refers to the connection with the Lombard and describes Eduard Riggenbach's discovery on the exegesis of Hebrews whereby Hervaeus's texts are appearing under the name of Remigius in the Lombard's exegesis..$^{20}$ Regarding this connection, Landgraf proposes the existence of a manuscript of Remigius, which contained the exegesis of Hebrews of Hervaeus and which was on hand to the Lombard. ${ }^{21}$ According to this, it could be summarized, that Landgraf - similar to Glunz, but by perpetuation of the authorship - estimates the Lombards commentary on Paul depending on Hervaeus' Enarrationes, whereas Smalley at least regards this possibility critically because of the richness of detail of the Enarrationes.

In contrast, a new position is appearing by Marcia Colish in her biography on the Lombard: She reverses the relationship and makes the case, that Hervaeus would have known both the Lombard's commentary on Paul and Abelard's one. ${ }^{22}$ This theory would have exciting effects: Because of Hervaeus death around 1150, ${ }^{23}$ the genesis of the first version of the Lombard's Collectanea around 1148 would be implausible; mainly because this version would have

16 On this mainly Smalley, 24-27.

17 Smalley, 38.

18 Cf. Smalley, 38.

19 Artur Michael Landgraf: Der Paulinenkommentar des Hervaeus von Bourg-Dieu, in: Biblica 21 (1940), 113-132; cf. on this especially the opinion on page 132.

20 Cf. Eduard Riggenbach: Historische Studien zum Hebräerbrief. I. Teil: Die ältesten Lateinischen Kommentare zum Hebräerbrief. Ein Beitrag zur Geschichte der Exegese und zur Literaturgeschichte des Mittelalters, Leipzig 1907, $231 \mathrm{f}$.

21 Cf. Landgraf, $127 f$.

22 „The exact date of his work is not known, but it clearly post-dates the Pauline commentaries of Peter Abelard and Peter Lombard, because Hervaeus makes use of their introducy remarks in his own accessus." (Colish, 190); „The only contemporary exegete of Paul who also quotes chunks of the apostle's text before adding his own analysis is Hervaeus of Bourg-Dieu. But, as we have noted, Hervaeus wrote after Peter Lombard and may well have derived this idea from him." (Colish, 193).

23 Cf. Oury, 373. The only source informing about the life of Hervaeus is a letter about Hervaeus' death; this letter is arranged in PL 181, 9-12 and describes also a chronological list of Hervaeus' works, cf. Oury, 374. 
needed to be taken from Paris to Bourg-Dieu, where Hervaeus in his last years before his death would have read the Lombard's commentary and cited it on a grand scale in his Enarrationes, and afterwards would have composed a commentary on the Twelth Prophets and on Genesis. ${ }^{24}$ According to this, the also by Colish proposed earlier dating of the Collectanea's first version around 1140 seems more likely; otherwise, a reversed dependency of the Lombard on Hervaeus has to explain the way of the Enarrationes ${ }^{25}$ to Paris, so that they could have been cited there by the Lombard in reduced quantity. But before the kind of formation of the dependency can be discussed, it firstly has to be researched, what kind of dependency at all exists.

\section{II}

In this comparison it will be researched on the basis of the Praefatio ${ }^{26}$ and the commentary on Romans ${ }^{27}$ of both of the commentaries on Paul if and in what way a dependency exists between the Lombard's Collectanea and the Enarrationes of Hervaeus. On regarding both commentaries alongside, several accordances are attracting attention: throughout the works distributed sentences or parts of sentences, which are equal to each other, partially on wording, and even sporadically distributed longer sections with several sentences. Concretely, there are around 300 sentences or parts of sentences, which are to be found identical or almost identical in both commentaries and which do not belong to the common biblical original. This result encourages to check the accordances accurately.

24 „Ad ultimum cum fama doctrinae ejus circumquaque spargeretur, et jam nullus ei, sicut attestantur, qui eum veraciter cognoverunt, canonicarum Scripturarum scientia primus haberetur, Librum duodecim Prophetum et librum Genesis ex integro tam mirabili sensu exposuit, ut expositionem super illos necdum potuerimus invenire, quae suae aequiparari possit." (PL 181, 11f.).

25 There are moreover only less manuscripts of the Enarrationes preserved, cf. Friedrich Stegmüller: Repertorium Biblicum Medii Aevi III, 50f. (No. 3276-3289).

26 To dependencies within the Praefatio respectively the accesus points already Marcia Colish, cf. Colish, 190.

27 The version printed by Migne (PL 191, 1297-1534) corresponds to the Lombard's Collectanea in its second, revised edition, which was propably only around 1154 completed (cf. Brady, $63^{\star} .72^{\star}$ ).For this reason, the manuscript Vat. lat. 144 was consulted as the older, original version of Collectanea in this comparison, which was furthermore compared with the manuscripcts Vat. lat. 695 and Paris Nat. lat. 17246; therefore, three of the four remaining manuscripts of the original version, specified by Brady (cf. Brady, $65^{\star}-68^{\star}$ ), were able to be used. For the commentary of Hervaeus of Bourg-Dieu, the version printed by Migne was used (PL 181, 591-814). 
First of all, the Praefatio should be analysed: Concerning this, Marcia Colish - as above-mentioned - postulated, that Hervaeus used in his Praefatio the ones of the Lombard and Abelard. This would be amongst other reasons noticeable insofar, as the Lombard himself obviously didn't use Abelard's commentary on Romans. However, in an accurate comparison of the three prefaces there are no major textual accordances to be found, which could prove the postulated dependency. In the Lombard's Praefatio and the one of Hervaeus are two corresponding sentences.

\begin{tabular}{|c|c|}
\hline Enarrationes, PL 181, 593A-B & Collectanea, Ms. Vat. lat. 144, fol. 1r \\
\hline $\begin{array}{l}\text { quod est legis supplementum, et in quo no- } \\
\text { bis exempla et praecepta vivendi plenissime } \\
\text { digesta sunt, has epistolas voluit ad singulas } \\
\text { ecclesias destinare, scilicet ut in initio na- } \\
\text { scentis ecclesiae novis causis existentibus, } \\
\text { et praesentia atque orientia resecaret vitia et } \\
\text { post futuras excluderet quaestiones. }\end{array}$ & $\begin{array}{l}\text { atque eumdem populum bonorum repro- } \\
\text { missionibus ab obediendum ac serviendum } \\
\text { Domino viventi commoneret, ita in Novo } \\
\text { Testamento post Evangelium, in quo Chri- } \\
\text { stianae religionis ordo et perfecte sanctitatis } \\
\text { doctrina traditur, epistolarum Pauli et alio- } \\
\text { rum perutilis secuta est doctrina, ut eccle- } \\
\text { siam Dei contra hereticas praemuniret pra- } \\
\text { vitates, et suborientia vitia resecaret, et post } \\
\text { futuras quaestiones excluderet. }\end{array}$ \\
\hline
\end{tabular}

Though this accordance is comparatively short, it is long enough to eliminate an accidental independent wording. However, it is not proving a dependency, for its origin lays in the commentary on Romans of Rabanus Maurus, ${ }^{28}$ who is frequently cited both by Hervaeus and the Lombard, wherefore the reason of the accordance is probably the common source.

Similar is the second accordance:

\begin{tabular}{|c|c|}
\hline Enarrationes, PL 181, 595B & Collectanea, Ms. Vat. lat. 144 , fol. $2 \mathrm{v}$ \\
\hline $\begin{array}{l}\text { In hac igitur epistola docere intendit Aposto- } \\
\text { lus omnibus venisse gratiam evangelii Christi. } \\
\text { Quam et idcirco gratiam vocari ostendit, quia } \\
\text { non quasi debitum justitiae redditum est, sed } \\
\text { gratuito datum. }\end{array}$ & $\begin{array}{l}\text { Pro altercatione itaque praedicta scribit Ro- } \\
\text { manis, confutans modo gentiles, modo Iude- } \\
\text { os, docens eos humiliari, ut omnia attribuant } \\
\text { gratiae Dei, et ostendens Dominus omnibus } \\
\text { gratis venisse gratiam fidei et Evangelii Chri- } \\
\text { sti: quam propterea et gratiam vocari ostendit, } \\
\text { quia non quasi debitum iustitiae reddita est, } \\
\text { sed gratuito data. }\end{array}$ \\
\hline
\end{tabular}

28 Cf. Rabanus Maurus: Enarrationum in Epistolas Beati Pauli. Prologus (PL 111, 1275C). 
Here as well a common ground can be found, namely Augustine. ${ }^{29}$ Furthermore the Lombard supplemented the text compared to Hervaeus, which argues against a dependancy of Hervaeus on the Lombard.

In contrast, in the Praefatio of Peter Abelard ${ }^{30}$ is not one accordance with Hervaeus to be found. There are only structural accordances, for example discussing intentio and materia of the Pauline Epistles in general and the Epistle on Romans in particular, but even in this case the three commentaries are deviating from each other. ${ }^{31}$ The proof mentioned by Marcia Colish, that the three commentaries are explaining the primacy of the Epistle on Romans in the canon of the Pauline Epistles not by its chronical composition, but by the dignity of the Romans, ${ }^{32}$ is just partially correct: It is mentioned in all of them, ${ }^{33}$ but literal accordances exist only between Abelard and Peter Lombard, who are both citing the prologue of Pseudo-Haimo of Halberstadt, ${ }^{34}$ whereas Hervaeus is using different wording. Insofar, it is to assert on the hand that there is no dependency in the Praefatio at all between these commentaries to be found, and on the other hand it is by now to note that literal accordances can always be founded on the use of common sources.

After these first findings regarding the accordances of the Lombard's commentary on Romans with the one of Hervaeus one is led to the surprising conclusion, that - looking on the wording and additions - at first sight, both possibilities of dependency are plausible, a citation of the Lombard by Hervaeus as well as use of the Enarrationes by the Lombard.

For example, Hervaeus of Bourg-Dieu seems to be citing the Lombard in his exegesis of Rom 5,12-13, in which he is enlarging the Lombard's demonstration by several points:

29 Cf. Augustine: Epistolae ad Romanos Inchoata Expositio, 1 (CSEL 84, 145).

30 Cf. Abelard: Expositio in epistolam ad Romanos. Römerbriefkommentar, übersetzt und eingeleitet von Rolf Peppermüller, 62-76.

31 Cf. PL 181, 594D-596C; Vat. lat. 144 fol. 2v; Abelard: Expositio in epistolam ad Romanos, 64-76.

32 Cf. Colish, $190 f$.

33 Cf. PL 181, 594C; Vat. lat. 114 fol. 2r; Abelard: Expositio in epistolam ad Romanos, 76.

34 Cf. Pseudo-Haimo of Halberstadt: In Divini Pauli Epistolas. Prologus (PL 117, $363 \mathrm{~A}-\mathrm{B})$. Beyond that, this theme appears also in the Praefatio of the commentary on Romans of Rabanus Maurus (Vgl. PL 111, 1275D-1276C) and in the one of Bruno of Cologne (PL 153, 12A); the bare treatment of the primacy of the letter on Romans isn't therefore much good to prove dependecies. 


\begin{tabular}{|c|c|}
\hline nes, PL 181, 661A & Collectanea, Ms. Vat. lat. 144 , fol. $29 \mathrm{v}$ \\
\hline $\begin{array}{l}\text { Nunc prolixius disputare inchoat de duobus } \\
\text { hominibus: uno primo Adam, per cujus pecca- } \\
\text { tum et mortem tanquam haereditariis malis et } \\
\text { posteri ejus obligati sumus; altero autem secun- } \\
\text { do Adam, qui non homo tantum, sed et Deus } \\
\text { est. Quo pro nobis solvente quod non debebat, } \\
\text { a debitis et paternis et propriis liberati sumus. } \\
\text { Proinde, quoniam propter unum illum ten- } \\
\text { ebat diabolus omnes per ejus vitiatam carnem } \\
\text { concupiscentialiter generatos, justum est, ut } \\
\text { propter hunc unum dimittat omnes per ipsius } \\
\text { immaculatam gratiam spiritaliter regeneratos. }\end{array}$ & $\begin{array}{l}\text { Prolixius ergo hic Apostolus de duobus } \\
\text { disputat, scilicet de primo Adam, per cujus } \\
\text { peccatum tanquam haereditariis malis posteri } \\
\text { eius obligati sumus; et de secundo Adam, } \\
\text { quo, solvente pro nobis quod non debebat, } \\
\text { a debitis et paternis et propriis liberati sumus. } \\
\text { Quia ergo per illum unum diabolus omnes } \\
\text { tenebat, per eius vitiatam carnem concupis- } \\
\text { centialiter generatos, iustum est ut per hunc } \\
\text { unum dimittat omnes per eius gratiam im- } \\
\text { maculatam spiritualiter regeneratos. }\end{array}$ \\
\hline
\end{tabular}

In this case, the accordances are seen clearly, in which - disregarding divergent filler words - Hervaeus is placing some insertions. However, also in this accordance there is a common source: The wording comes from Augustine's De Trinitate ${ }^{35}$ which was also used by Rabanus Maurus ${ }^{36}$ and William of StThierry, ${ }^{37}$ so that it is probable that Hervaeus and the Lombard got the words from one of these three.

A little bit different are the exegeses of Rom 8,35-37:

\begin{tabular}{|c|c|}
\hline Enarrationes, PL 181, 719C-D & Collectanea, Ms. Vat. lat. 144 , fol. 46v \\
\hline $\begin{array}{l}\text { Num faciet hoc tribulatio, id est corporis } \\
\text { afflictio? Nequaquam. An angustia, id est } \\
\text { mentis anxietas hoc facere poterit, ut non } \\
\text { diligamus Christum? Minime. }\end{array}$ & $\begin{array}{l}\text { Nunquid separabunt nos haec adversa, } \\
\text { scilicet separabit nos tribulatio, id est corporis } \\
\text { afflictio, an angustia, id est mentis anxietas, }\end{array}$ \\
\hline $\begin{array}{l}\text { An persecutio, id est de loco ad locum expulsio, } \\
\text { separabit nos a Christi dilectione? Non. Etsi } \\
\text { omnimodam tribulationem sustineamus, } \\
\text { etsi animi angustia torqueamur, etsi nos } \\
\text { adversarii per diversa loca persequantur, } \\
\text { nunquam a Christi amore divelli poterimus. } \\
\text { An nos ab eo fames separabit, id est } \\
\text { desiderium comedendi sine abundantia }\end{array}$ & $\begin{array}{l}\text { an persecutio, quae est de loco ad locum, an } \\
\text { fames, id est penuria cibi, }\end{array}$ \\
\hline $\begin{array}{l}\text { cibi? Absit! An nuditas, id est penuria vestis } \\
\text { hoc faciet? Nequaquam. An periculum, id est }\end{array}$ & \\
\hline $\begin{array}{l}\text { apparatus mortis nos dividet a Christo? An } \\
\text { gladius, id est ipsa mors gladio facta valebit } \\
\text { hoc facere? Nequaquam. }\end{array}$ & $\begin{array}{l}\text { an periculum, id est apparatus mortis, } \\
\text { an gladius, scilicet ipsa mors? Nihil utique } \\
\text { eorum separabit. }\end{array}$ \\
\hline
\end{tabular}

35 Cf. Augustine: De Trinitate XII, cap. XVI, 21 (CChr.SL LA, 409f.).

36 Cf. Rabanus Maurus: Enarrationum in Epistolas Beati Pauli, Rom 5,13 (PL 111, 1382C-D).

37 Cf. William of St-Thierry: Expositio in Epistolam ad Romanos, lib. III, 19 (SC 544, 292). 
This example reveals how the Lombard's obviously coherent text is interrupted and explicated in many cases by Herveaus' own ideas. But there is also one possible source, which gives an even more interesting view on the topic: This passage could be the missing proof of a dependency on Abelard's commentary on Romans, where the following is written: „Tribulatio? Ac si diceret: Non. ,Tribulatio' dicitur quaecumque corporis afflictio ut verberatio, angustia mentis anxietas ut est metus, persecutio de loco ad locum propulsio, periculum mortis apparatus, gladius ipsa mors. ${ }^{\text {" }} 8$

However, the possible usage of the commentary of Abelard couldn't assert the identical formulation, equally is the explication of nuditas missing in Abelard's commentary. Insofar, this example would prove the thesis above, whereby Hervaeus did use the Lombard's commentary and enlarged it, whereby the Lombard had known Abelard's commentary. Besides the mentioned examples there are around 18 further parallels, where it looks like Hervaeus of Bourg-Dieu had used the Lombard's commentary as a source and added his own ideas. ${ }^{39}$

Indeed, there are contrary indications that the Lombard cited Hervaeus and enlarged his explanations with own ideas, what is exemplary seen on the exegesis of Rom 1,17:

\begin{tabular}{|l|l|}
\hline \multicolumn{1}{|c|}{ Enarrationes, PL 181, 608C } & \multicolumn{1}{|c|}{ Collectanea, Ms. Vat. lat. 144, fol. 11v } \\
\hline $\begin{array}{l}\text { Ex fide primi adventus Domini, in fidem } \\
\text { secundi. Ex fide resurrectionis primae, } \\
\text { in fidem secundae. }\end{array}$ & $\begin{array}{l}\text { Ex fide primi adventus, in fidem secundi, ut } \\
\text { utrumque credat ex fide primae resurrectionis, } \\
\text { quae est in anima, in fidem secundae quae } \\
\text { erit in corporibus. Ex fide promissionis, in } \\
\text { fidem redditionis, ut scilicet credat Deum } \\
\text { promisisse acreddidisse, vel redditurum fore; } \\
\text { ex fide praedicatorum in fidem populorum, ut } \\
\text { credat vel quod credint maiores. }\end{array}$ \\
$\begin{array}{l}\text { Ex fide praedicatorum, in fidem populorum. } \\
\text { Ex fide humanitatis Christi, in fidem ejus } \\
\text { divinitatis. }\end{array}$ & \\
\hline
\end{tabular}

38 Abelard: Expositio in epistolam ad Romanos, 586.

39 Cf. Ms. Vat. lat. 144, fol. 15v || PL 181, 617C; Ms. Vat. lat. 144, fol. 19v || PL 181, 628C; Ms. Vat. lat. 144, fol. 20r || PL 181, 630B-C; Ms. Vat. lat. 144, fol. 20v || PL 181, 632D633A; Ms. Vat. lat. 144, fol. 25v || PL 181, 648B; Ms. Vat. lat. 144, fol. 26r || PL 181, 648D; Ms. Vat. lat. 144, fol. 30r || PL 181, 662C-D; Ms. Vat. lat. 144, fol. 36v || PL 181, 680A; Ms. Vat. lat. 144, fol. 37r || PL 181, 682D; Ms. Vat. lat. 144, fol. 38v || PL 181, 685B; Ms. Vat. lat. 144, fol. 41V || PL 181, 696D-697A; Ms. Vat. lat. 144, fol. 47v || PL 181, 725C; Ms. Vat. lat. 144, fol. 54r || PL 181, 748A; Ms. Vat. lat. 144, fol. 55v || PL 181, 753B-C; Ms. Vat. lat. 144, fol. 62r || PL 181, 775C; Ms. Vat. lat. 144, fol. 62r || PL 181, 776B; Ms. Vat. lat. 144, fol. 655 || PL 181, 790A; Ms. Vat. lat. 144, fol. 67v-68r || PL 181, 806C. 
In this case, the comparatively short text of Hervaeus is apparently enlarged by the Lombard. Again, there is a potential common source, the commentary on Romans of Gilbert Porreta, which was - as being part of the media glosatu$r a$ - an predecessor of the Lombard's magna glosatura. Gilbert is explaining the passage as follows:

„In novo etiam proficit ex fide primi adventus, in fidem secundi; ex fide primae ressurectionis, in fidem secundae, ex fide promissionis, in fidem redditionis. Secundum personarum vero diversitatem perfectus est: ex fide seminantium prophetarum, in fidem metentium apostolorum; ex fide praedicatorum, in fidem populorum. " 40

In view of this possible source it is to reason, that the Lombard obtained his explanations from Gilbert; while Hervaeus either reflected an abbreviated form of the Lombard or Gilbert or he recorded an earlier shorter common version.

As a second point of comparision the exegesis on Rom 9,9 shall exemplify the possible dependency of the Lombard on Hervaeus:

\begin{tabular}{|l|l|}
\hline \multicolumn{1}{|c|}{ Enarrationes, PL 181, 726C } & \multicolumn{1}{|c|}{ Collectanea, Ms. Vat. lat. 144, fol. 47v } \\
\hline $\begin{array}{l}\text { Promissio facta Sarae vel Abrahae, ostendit } \\
\text { quod nullus propter genus salvatur; }\end{array}$ & $\begin{array}{l}\text { Et nota quod promissio facta Sarae ostendit } \\
\text { quod propter genus nullus salvabitur, cum } \\
\text { Ismael de Abraham natus reprobatus sit, } \\
\text { de quo eodem Isaac natus sola gratia est }\end{array}$ \\
$\begin{array}{l}\text { ista Rebeccae, } \\
\text { quod propter nullum meritum suum vel } \\
\text { parentum aliquis eligitur, sed sola gratia. }\end{array}$ & $\begin{array}{l}\text { salvatendit quod propter nullum meritum suum, } \\
\text { ostel parentum aliquis eligitur, sed sola gratia. }\end{array}$ \\
\hline
\end{tabular}

In this example, a homogeneous argumentation of Hervaeus is interrupted by the Lombard's own insertion, which is suggesting an extension by the Lombard.

Other than these mentioned examples, there are 16 further parallels where the Lombard possibly has cited Hervaeus. ${ }^{41}$

40 Ms. Cod. Paris. Nat. lat. 14441, fol. 2v-3r.

41 Cf. Ms. Vat. lat. 144, fol. 3r || PL 181, 598A-B; Ms. Vat. lat. 144, fol. 17v || PL 181, 622A; Ms. Vat. lat. 144, fol. 19r || PL 181, 625B-C; Ms. Vat. lat. 144, fol. 27r || PL 181, 654A-B; Ms. Vat. lat. 144, fol. 33v || PL 181, 669D; Ms. Vat. lat. 144, fol. 35v || PL 181, 677A; Ms. Vat. lat. 144, fol. 36v || PL 181, 681A-B; Ms. Vat. lat. 144, fol. 41v || PL 181, 696C; Ms. Vat. lat. 144, fol. 45v || PL 181, 714D-715A; Ms. Vat. lat. 144, fol. 46r || PL 181, 716B-C; Ms. Vat. lat. 144, fol. 48r || PL 181, 728D; Ms. Vat. lat. 144, fol. 50r || PL 181, 733C-D; Ms. Vat. lat. 144, fol. 52v || PL 181, 742B-C; Ms. Vat. lat. 144, fol. 66r || PL 181, 795A; Ms. Vat. lat. 144, fol. 67r || PL 181, 802D; Ms. Vat. lat. 144, fol. 69r || PL 181, 813C-814A. 
What is to infer from this result? There are two possible interpretations: Either one still postulates a relationship of dependency in the one or the other direction, in which the apparent extensions of the chronological first exegesis have to be explained as abbreviations in the chronological second, or there is just one apparent dependency by reason of both authors using the same sources. The latter interpretation has already been partially made plausible by the examples above; it is especially there probable, where both authors complete a common source in different ways, like in the exegesis of Rom 4,1-3:

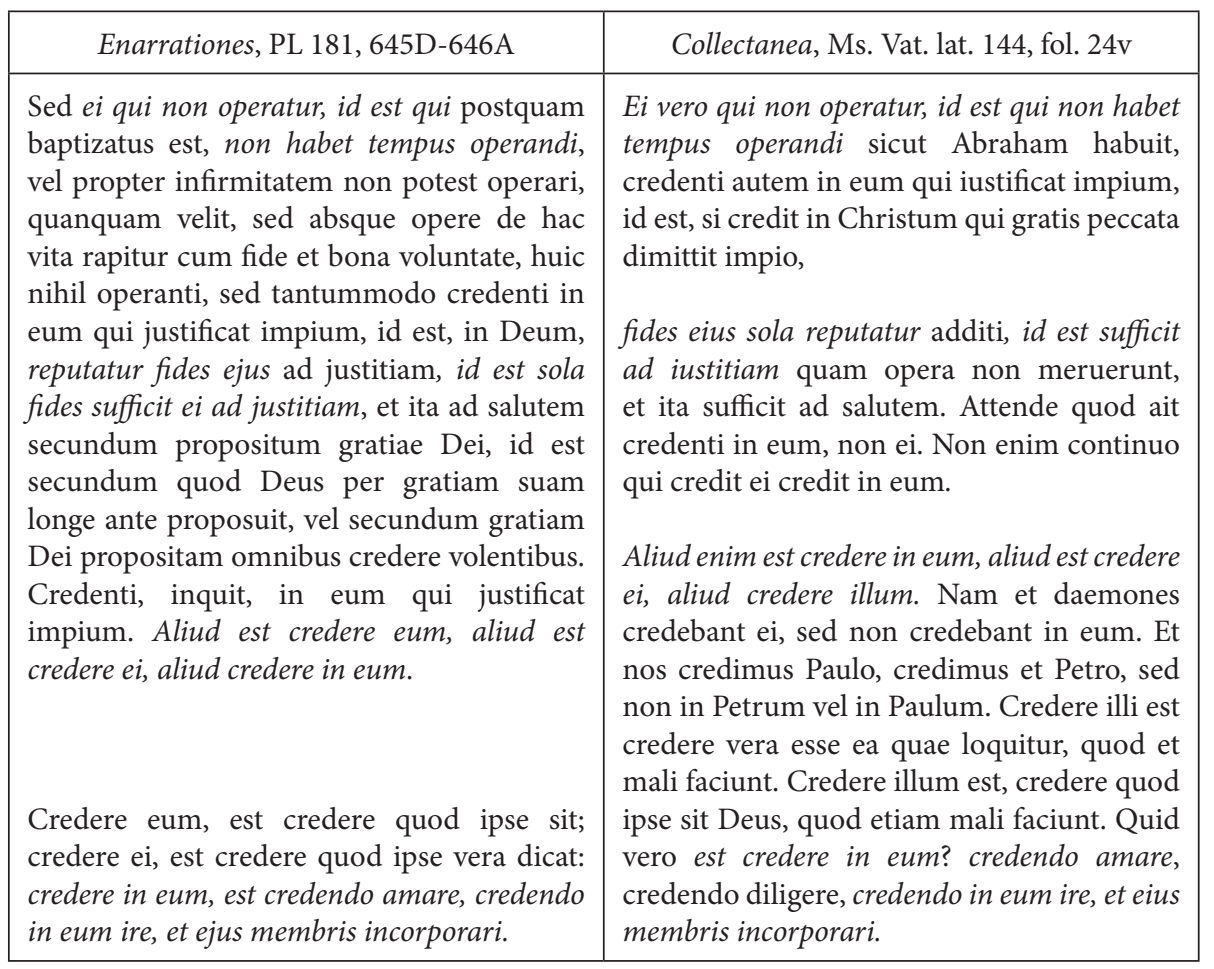

Here is an exegesis of Bruno of Cologne ${ }^{42}$ placed beside the definition of faith basing on Augustine ${ }^{43}$; between these parts, both the Lombard and Her-

42 „Ei vero qui non operatur, id est qui non habet tempus operandi ut pueri statim morientes, sed credenti in eum qui per fidem iustificat impium, illi reputatur fides eius ad iustitiam, id est sola fides sufficit ad iustificationem eius, cui tenera aetas opera negavit.“ (Expositiones in Epistolas Pauli, Rom 4; PL 153, 44B-C).

43 This definition has its origins in Augustine's In Johannis Evangelium Tractatus, XXIV, 6; LIV, 3 (CChr.SL XXXVI, 287; 460). It was elaborated by Pseudo-Augustine in his Sermo de Symbolo I (PL 40, 1190f). 
vaeus are adding different sections. This could be an indication of an independent adaption of the traditional material.

The traditional parts, which are recorded by both authors, but on different parts of their commentary, could be equally assessed. For example, the comparison of the law with medicine originating from Jerome ${ }^{44}$ is integrated by Hervaeus to his exegesis of Rom 7,7-8, ${ }^{45}$ by the Lombard to his exegesis of Rom $7,12-13 \cdot{ }^{46}$

\section{III}

However, there are also substantial arguments against the theory of an apparent dependency, which were already reminiscent in the adaption of Abelard above: There are many parallels where no common source is to be found and others, like the exegesis of Rom 8,35-37, where an identical enlargement of the source is an indication against an independent adoption of the source; aside from this there are parallels between the Lombard and Hervaeus, which are based on different common sources, but are combining these parts of the different sources without analogy. An independent genesis of both these commentaries is under these circumstances very improbable. By nevertheless defending the theory of an independence of each other, which could at least explain many of the noticeable problems above, one has to postulate a common source which is as of yet unknown; the environment of the origins of the Glossa ordinaria may offer a promising potential for such a source.

But as long as this hypothetical source isn't found, its existence has to be negated and the most probable explanation of the parallels between the Lombard and Hervaeus is an immediate dependency between both. But who depends on whom? While the examples above approve both possibilities, the following will show the implausibility of a dependency of Hervaeus on the Lombard: several parallels, in which both authors are using parts of the tradition, are revealing

44 „quomodo medicina non est causa mortis, si ostendat uenena mortifera, licet his mali homines abutantur ad mortem et uel se interficiant uel insidientur inimicis, sic lex data est, ut peccatorum uenena demonstret et hominem male libertate sua abutentem, qui prius ferebatur improvidus et praecipitia labebatur, freno legis retineat et conpositis doceat incedere gressibus." (Jerome: Epistola CXXI, cap. VIII; CSEL LVI/1, 30f.). The example reached probably the two commentators by the commentary on Romans of Rabanus Maurus, cf. Enarrationum in Epistolas Beati Pauli, Rom 7,13; PL 111, 1414D-1415A.

\footnotetext{
45 Cf. PL 181, 685A-B.

46 Cf. Ms. Vat. lat. 144, fol. 38v.
} 
that Hervaeus refers directly to the traditional literature. This can be shown on the exegesis of Rom 7,10-11:

\begin{tabular}{|c|c|c|}
\hline $\begin{array}{c}\text { Rabanus Maurus, } \\
\text { Enarrationum in Epistolas } \\
\text { Beati Pauli, Rom 7,11; PL } \\
\text { 111, 1420A }\end{array}$ & $\begin{array}{c}\text { Ennarationes, PL 181, } \\
\text { 687C-D }\end{array}$ & $\begin{array}{c}\text { Collectanea, Ms. Vat. lat. } \\
\text { 144, fol. } 38 \mathrm{r}\end{array}$ \\
\hline $\begin{array}{l}\text { fallax enim dulcedo est, quia } \\
\text { iam plures atque maiores poe- } \\
\text { narum amaritudines sequun- } \\
\text { tur. Quia ergo ab hominibus } \\
\text { nondum spiritalem gratiam } \\
\text { consequentibus suavius ad- } \\
\text { mittitur quod vetatur, fallit } \\
\text { peccatum falsa dulcedine: } \\
\text { quia vero etiam occidit, rea- } \\
\text { tus praevaricationis occidit. }\end{array}$ & $\begin{array}{l}\text { Fallax enim dulcedo est, } \\
\text { quam plures atque majores } \\
\text { poenarum amaritudines se- } \\
\text { quuntur. Quia ergo ab ho- } \\
\text { minibus nondum spiritalem } \\
\text { gratiam consequentibus } \\
\text { suavius admittitur quod ve- } \\
\text { tatur, fallit peccatum falsa } \\
\text { dulcedine; quia vero accedit } \\
\text { etiam reatus praevaricatio- } \\
\text { nis, occidit. }\end{array}$ & $\begin{array}{l}\text { Et hoc est, nam peccatum, } \\
\text { id est carnalitas vel diabolus, } \\
\text { seduxit me, id est a bono ad } \\
\text { malum traxit me. Occasione } \\
\text { accepta per mandatum. Quia } \\
\text { quod concupiscitur, dulcius } \\
\text { fit dum vetatur, et sic pec- } \\
\text { catum fallit per mandatum. } \\
\text { Ex prohibitione namque ubi } \\
\text { charitas deficit, desiderium } \\
\text { mali crescit, quo aucto dul- } \\
\text { cius fit quod prohibetur, et } \\
\text { ita peccatum fallit falsa dul- } \\
\text { cedine. Fallax enim est dul- } \\
\text { cedo quam plures atque ma- } \\
\text { iores poenarum amaritudines } \\
\text { sequuntur, et non solum se- } \\
\text { duxit per mandatum, sed et } \\
\text { per illud, mandatum occidit, } \\
\text { quia etiam reatus praevarica- } \\
\text { tionis accessit. Gladio ergo } \\
\text { quem portabas te inimicus } \\
\text { occidit, armis tuis te vicit, ar- } \\
\text { mis tuis te interemit. }\end{array}$ \\
\hline
\end{tabular}

This example shows the fact, that Hervaeus got the corresponding parts obviously not by the Lombard, but by Rabanus Maurus or another source ${ }^{47}$; all the while, the Lombard could have picked up the wording of Hervaeus and enlarged it, or he got the citation of Rabanus by another source.

47 Beside Rabanus Maurus, the same version is also read by William of St-Thierry, cf. Expositio in Epistolam Romanos, lib. IV, 13 (SC 568, 30). 
A similar result can be found by comparing the exegeses of Rom 8,12-14:

\begin{tabular}{|c|c|c|}
\hline $\begin{array}{c}\text { Rabanus Maurus, } \\
\text { Enarrationum in Epistolas } \\
\text { Beati Pauli, Röm 8,14; PL } \\
\text { 111, Sp. 1448A }\end{array}$ & $\begin{array}{c}\text { Enarrationes, PL 181, } \\
\text { Sp. 705C }\end{array}$ & $\begin{array}{c}\text { Collectanea, Ms. Vat. lat. } \\
\text { 144, fol. 43v }\end{array}$ \\
\hline $\begin{array}{l}\text { Non littera sed spiritu, non } \\
\text { lege praecipiente, minan- } \\
\text { te, promittente, sed spiritu } \\
\text { exhortante, illuminante, } \\
\text { adiuvante, hos dicit Spiritu } \\
\text { Dei agi, in quorum actibus } \\
\text { consilia principum et po- } \\
\text { testatum huius mundi non } \\
\text { videntur }\end{array}$ & $\begin{array}{l}\text { Non ergo littera, sed spiritu; } \\
\text { non lege praecipiente, mi- } \\
\text { nante, promittente; sed spi- } \\
\text { ritu exhortante, illuminante, } \\
\text { adjuvante aguntur. Non quia } \\
\text { ipsi nihil agant, sed ne nihil } \\
\text { agant boni, a bono aguntur } \\
\text { ut agant. }\end{array}$ & $\begin{array}{l}\text { Quicumque enim aguntur, } \\
\text { id est reguntur, spiritu Dei, } \\
\text { non suo, non lege minante, } \\
\text { praecipiente, promittente, } \\
\text { non adiuvante, hii sunt filii } \\
\text { Dei, id est ex dilectione ser- } \\
\text { vientes. Vel aguntur dicit, } \\
\text { non reguntur, ut magnum } \\
\text { gratiae effectum ostendat. }\end{array}$ \\
\hline
\end{tabular}

Even in this shorter parallel between Hervaeus and Peter Lombard it can be seen, that Hervaeus keeps the original context of the citation, whereas the Lombard changes this context.

These two examples and several other parallels make the conclusion plausible, that in case of an immediate dependency between Peter Lombard and Hervaeus of Bourg-Dieu, Herveaus' Enarrationes were almost certainly used by the Lombard, enlarged and - considering the problems presented above - even abbreviated in some parts. The contrary case of Hervaeus using the Lombard's Collectanea by writing his Enarrationes is in light of the just presented connections most disputable; Hervaeus would have had cited elaborately the Lombard's version, while at the same time deciding against this version by using the original versions for his citation instead.

In view of these results, the possibility of an early dating of the Collectanea's first version, which was brought up in the beginning, has to be negated; if the Collectanea really depended on the Enarrationes, this would rather be an argument for the later dating on 1148. Even if there existed a common source of both commentaries, which would thereby be independent of each other, it could of course influence the dating, but as long as this source remains a hypothetical one, a dependency of the Lombard on Hervaeus has to be supposed this leads on the one hand to another indication for the date of writing the Collectanea, on the other hand to Hervaeus of Bourg-Dieu being attributed a special influence on the magna glosatura, which was as of yet neither considered nor investigated. 


\section{Bibliography}

\section{Manuscripts}

Cod. Vat. lat. 144

Cod. Vat. lat. 695

Cod. Paris. Nat. lat. 14441

Cod. Paris Nat. lat. 17246

\section{Sources}

Abelard: Expositio in epistolam ad Romanos. Römerbriefkommentar, übersetzt und eingeleitet von Rolf Peppermüller, Freiburg i.Br. 2000.

Augustine: De Trinitate libri XIII-XV (CChr.SL 50A), Turnhout 1968.

Augustine: Epistolae ad Romanos Inchoata Expositio, in: Sancti Augustini Opera. Sect. IV Pars I (CSEL 84), Vienna 1971, 143-181.

Augustine: In Johannis Evangelium Tractatus CXXIV (CChr.SL 36), Turnhout 1954.

Bruno of Cologne: Expositiones in Epistolas Pauli, in: PL 153, Paris 1880, 9-570.

Herveus of Bourg-Dieu: Enarrationes in Epistolas Pauli, in: PL 181, Paris 1854, 591-1692.

Herveus of Bourg-Dieu: Notitia, in: PL 181, 9-14.

Jerome: Epistola CXXI-CLIV (CSEL 56/1), Vienna ${ }^{2} 1996$.

Peter Lombard: Collectanea in Epistolas S. Pauli, in: PL 191, Paris 1879, 1297-1534.

Pseudo-Augustine: Sermo de Symbolo, in: PL 40, Paris 1887, 1189-1202.

Pseudo-Haimo of Halberstadt: Ennaratio in Divini Pauli Epistolas, in: PL 117, Paris 1881, 361-938.

Rabanus Maurus: Enarrationum in Epistolas Beati Pauli, in: PL 111, Paris 1864, 1273-1616.

William of Saint-Thierry: Exposé sur l'épître aux Romains. Tome I: Livres I-III (SC 544), Paris 2011.

\section{References}

Andrée, Alexander: Anselm of Laon unveiled: The Glosae svper Iohannem and the origins of the Glossa ordinaria on the Bible, in: Mediaeval Studies 73 (2011), S. 217-240.

Brady, Ignatius: Prolegomena, in: Magistri Petri Lombardi Sententiae in IV libris distinctae, ed. Ignatius Brady (Spicilegium Bonaventurianum 4), Grottaferrata $1971,8^{\star}-129^{\star}$.

Classen, Peter: Gerhoch von Reichersberg. Eine Biographie, Wiesbaden 1960.

Colish, Marcia L.: Peter Lombard, Leiden/New York/Cologne 1994. 
Glunz, Hans Hermann: History of the Vulgate in England from Alcuin to Roger Bacon. Being an Inquiry into the Text of some English Manuscripts of the Vulgate Gospels, Cambridge 1933.

Gross-Diaz, Theresa: The Psalms Commentary of Gilbert of Poitiers. From Lectio Divina to the lecture room, Leiden/New York/Cologne 1996.

Landgraf, Artur Michael: Der Paulinenkommentar des Hervaeus von Bourg-Dieu, in: Biblica 21 (1940), 113-132.

Oury, Guy: Art. Hervé de Bourg-Dieu, in: DSP 7, 373-377.

Riggenbach, Eduard: Historische Studien zum Hebräerbrief. I. Teil: Die ältesten Lateinischen Kommentare zum Hebräerbrief. Ein Beitrag zur Geschichte der Exegese und zur Literaturgeschichte des Mittelalters, Leipzig 1907.

Rosemann, Philipp W.: Peter Lombard, Oxford/New York 2004.

Smalley, Beryl: Gilbertus Universalis, Bishop of London (1128-34), and the Problem of the, Glossa Ordinaria', in: RThAM 8 (1936), 24-60.

Stegmüller, Friedrich: Repertorium Biblicum Medii Aevi III: Commentaria. Auctores H-M, Madrid 1951. 